\title{
International Adoption: Journey of An Indian Girl from a Child Care Institute to France
}

\author{
Bhavneet Bharti ${ }^{1} \cdot$ Prahbhjot Malhi $^{1}$
}

Received: 5 August 2020 / Accepted: 10 September 2020 / Published online: 15 September 2020

(C) Dr. K C Chaudhuri Foundation 2020

To the Editor: We share the travails and joys of a young girl from a child care institute who undertook the difficult journey to France to highlight the critical importance of pre-adoption preparation in promoting resilient outcomes among adoptees. $\mathrm{R}$ was found abandoned in a city park around age 3 and after multiple unsuccessful attempts to locate her family she was housed in a child care facility. She was moderately stunted and displayed several social and behavioral deficits.

A pre-adoption individualized plan was drawn up to facilitate her post adoption transition to France. The therapeutic plan focused on improving attachment, behavior and language skills. A weekly $2 \mathrm{~h}$ visit to the home of the pediatrician was implemented wherein $\mathrm{R}$ was exposed to a loving, wellresourced home environment; with plentiful opportunities for free unstructured play, access to toys, and practice in French language. After 6 mo of intervention, positive overall gains in development, language and behavior were observed. Follow up done at 2 years' post-adoption at age eight, showed $\mathrm{R}$ had caught up on growth parameters, academics, and reading, and spoke French fluently.

The increase in the number of intra country adoptions of institutionalized children in India, coordinated by the Central Adoption Resource Authority (CARA), has provided an impetus to research on risk and protective factors determining outcomes in adopted children [1]. Research indicates that internationally adopted children show substantial catching-up in growth parameters as well as in developmental abilities, especially if they have been adopted from extremely impoverished conditions [2]. Indeed, a dose related response has generally been reported and longer the children are exposed to early adversity more the risk for subsequent attachment and behavioral difficulties [3]. Evidence indicates that the degree of

Prahbhjot Malhi

pmalhi18@hotmail.com

1 Department of Pediatrics, Post Graduate Institute of Medical Education and Research, Sector 12, Chandigarh 160012, India recovery is related to two variables namely, age at adoption and duration of stay in the child care facility [4]. In India, many children are given up after adoption due to inadequate pre-adoption preparation [5]. This case demonstrates that pediatricians can play a critical role in determining a positive post-adoption outcome by implementing an individualized intervention plan for preparing a child exposed to the pernicious experience of institutional care.

\section{Compliance with Ethical Standards}

Conflict of Interest None.

\section{References}

1. Government of India, Ministry of Women and Child Development. Report of the Committee for Analysing Data of Mapping and Review Exercise of Child Care Institutions Under the Juvenile Justice (Care and Protection of Children) Act, 2015. Main report. Vol 1, 2018.

2. Loman MM, Wiik KL, Frenn KA, Pollak SD, Gunnar MR. Postinstitutionalized children's development: growth, cognitive, and language outcomes. J Dev Behav Pediatr. 2009;30:426-34.

3. Wade M, Fox NA, Zeanah CH, Nelson CA. Long-term effects of institutional rearing, foster care, and brain activity on memory and executive functioning. Proc Natl Acad Sci U S A. 2019;116:180813.

4. Julian MM. Age at adoption from institutional care as a window into the lasting effects of early experiences. Clin Child Fam Psychol Rev. 2013;16:101-45.

5. Jones VF. Schulte EE; Committee on Early Childhood; Council on Foster Care, Adoption, and Kinship Care. The pediatrician's role in supporting adoptive families. Pediatrics. 2012;130:e1040-9.

Publisher's Note Springer Nature remains neutral with regard to jurisdictional claims in published maps and institutional affiliations. 